\title{
Effects of tumour necrosis factor alpha (TNF $\alpha$ ) on glucose transport and lipid metabolism of newly-differentiated human fat cells in cell culture
}

\author{
H. Hauner, Th. Petruschke, M. Russ, K. Röhrig, J. Eckel \\ Diabetes Research Institute, Heinrich-Heine-University, Düsseldorf, Germany
}

\begin{abstract}
Summary Tumour necrosis factor alpha (TNF $\alpha$ ) has been found to cause a delipidation of fat cells and a decrease of the adipose tissue mass. In the present study, we tried to elucidate some of the mechanisms responsible for this phenomenon by investigating the action of TNF $\alpha$ on specific pathways which are involved in lipid storage. Cultured stromal cells from human adipose tissue were induced to differentiate into adipose cells by exposure to adipogenic factors and subsequently used for studying the effects of $\mathrm{TNF} \alpha$ on fat cell metabolism. Presence of $5 \mathrm{nmol} / \mathrm{l}$ $\mathrm{TNF} \alpha$ for $24 \mathrm{~h}$ resulted in a complete loss of the stimulatory effect of insulin on 2-deoxy-glucose transport. This inhibitory action was paralleled by a decrease of GLUT4 protein and mRNA levels. The amount of cellular GLUT4 protein was reduced by $49 \pm 3 \%$ after a 24 -h exposure and by $82 \pm 18 \%$ after a 72 -h exposure to $5 \mathrm{nmol} / \mathrm{l} \mathrm{TNF} \alpha$. GLUT4 $\mathrm{mRNA}$ was almost undetectable after a 24 -h incubation with
\end{abstract}

$5 \mathrm{nmol} / \mathrm{l} \mathrm{TNF} \alpha$ In a similar time-dependent manner, TNF $\alpha$ dramatically reduced the lipoprotein lipase mRNA content of the cells. Furthermore, incubation of cultured human fat cells with $\mathrm{TNF} \alpha$ resulted in a marked dose-dependent stimulation of lipolysis, assessed by glycerol release, by up to $400 \%$ above controls, which became apparent after a 6-h exposure at the earliest. These data suggest that TNF $\alpha$ induces a catabolic state in human adipose tissue which includes a loss of the stimulatory effect of insulin on glucose transport. These multiple actions of TNF $\alpha$ may contribute to the loss of adipose tissue observed during cachexia in man. [Diabetologia (1995) 38: 764-771]

Key words Cachexia, glucose transport, human adipocytes, insulin resistance, lipolysis, tumour necrosis factor alpha.
Received: 19 August 1994 and in revised form: 12 December 1994

Corresponding author: Dr. H. Hauner, Diabetes Research Institute, Heinrich-Heine-University Düsseldorf, Auf'm Hennekamp 65, D-40225 Düsseldorf, Germany

Abbreviations: TNF $\alpha$, Tumour necrosis factor alpha; LPL, lipoprotein lipase; HEPES, N-2-Hydroxyethylpiperazine-N-2ethanesulfonic acid; MIX, 1-Methyl-3-isobutylxanthine; BSA, bovine serum albumin; GPDH, glycerophosphate dehydrogenase; PBS, phosphate buffered saline.

The main results of this study have been presented in abstract form at the Keystone-Symposium "The Adipose Cell", January 1994, Park City, Utah, USA
Tumour necrosis factor alpha (TNF $\alpha$ ), a $17-\mathrm{kD}$ polypeptide synthesized mainly by activated macrophages but also by many other tissues, is known to exert pleiotropic metabolic effects in many species $[1,2]$. Numerous in vivo and in vitro studies have tried to characterize the metabolic actions of TNF $\alpha$. It was demonstrated in cell lines and animal experiments that this cytokine is able to decrease lipoprotein lipase activity [3-8], increase lipid mobilization from adipose tissue $[4,9-12]$ and stimulate de novo hepatic lipogenesis with the latter effect being probably dominant for the development of hypertriglyceridaemia [13, 14]. However, conflicting results have been reported from human studies. TNF $\alpha$ was not found to suppress lipoprotein lipase activity (LPL) activity in cultured human adipose cells [15], while LPL activity and 
synthesis were decreased when human adipose tissue fragments were cultured in the presence of TNF $\alpha$ [16]. We have recently reported that TNF $\alpha$ is able to suppress glycero-3-phosphate dehydrogenase activity, a lipogenic key enzyme, in cultured human fat cells in a time- and dose-dependent manner [17].

Other studies have shown that TNF $\alpha$ causes pronounced alterations in glucose metabolism that are similar to those observed in patients with chronic inflammatory diseases. These changes include an enhanced utilization of glucose mainly by muscle but also by other tissues, and an increased glucose production [18-20]. However, under hyperinsulinaemic clamp conditons the amount of glucose required to maintain euglycaemia was significantly reduced indicating a state of insulin resistance. The ability of insulin both to suppress hepatic glucose production and to stimulate peripheral glucose utilization was impaired in the presence of TNFa [21]. Recent studies in 3T3 L1 adipocytes suggest that TNF $\alpha$-induced insulin resistance could be due to a transcriptional suppression of the GLUT4 gene resulting in a total depletion of insulin-sensitive glucose transporters [22]. A direct role of TNF $\alpha$ in the development of insulin resistance has been implicated by a recent study in genetically obese rodents that indicates an association between an increased expression of TNFa in adipose cells and insulin resistance [23]. These recent findings and our observation of a delipidation of human fat cells by TNF $\alpha$ under long-term exposure prompted us to study the effects of TNF $\alpha$ on metabolic pathways that are involved in the regulation of lipid storage in human adipose tissue. For this purpose, we used the model of newly-differentiated human fat cells which can be cultured for extended periods of time.

\section{Materials and methods}

Chemicals. Human transferrin, triiodothyronine $\left(\mathrm{T}_{3}\right)$, pantothenate, and bovine serum albumin (BSA) were purchased from Sigma (Munich, Germany). 1-methyl-3-isobutylxanthine was from Serva (Heidelberg, Germany). Collagenase CLS type 1 was obtained from Worthington (Freehold, N.J., USA). Semisynthetic human insulin and cortisol were kindly donated by Hoechst (Frankfurt, Germany). Fetal bovine serum and media were from Biochrom (Berlin, Germany). Recombinant human TNFa, antibiotics, trypsin-EDTA solution, glycerol kinase, glycerol 3-phosphate dehydrogenase, triosephosphate isomerase, flavin mononucleotide reductase and luciferase were obtained from Boehringer (Mannheim, Germany). Sterile plastic ware for tissue culture was purchased from Flow Laboratories (Irvine, UK).

2-Deoxy-D-(1- $\left.{ }^{3} \mathrm{H}\right)$ glucose $\quad(15 \mathrm{Ci} / \mathrm{mmol}), \quad\left(\alpha_{-}{ }^{32} \mathrm{P}\right) \mathrm{dCTP}$ $(3000 \mathrm{Ci} / \mathrm{mmol})$ and ${ }^{125}[$-labelled protein $\mathrm{A}(30 \mathrm{mCi} / \mathrm{mg})$ were from Amersham (Braunschweig, Germany). ( $\left.\gamma^{32} \mathrm{P}\right) \mathrm{ATP}$ $(6000 \mathrm{Ci} / \mathrm{mmol})$ was from New England Nuclear (Dreieich, Germany). Reagents for SDS-PAGE were supplied by Pharmacia (Freiburg, Germany) and Sigma. Polyclonal GLUT1and GLUT4-antisera were a product of Calbiochem (Bad So- den, Germany). All other chemicals were of the highest purity grade available and were purchased from Sigma and from Merck (Darmstadt, Germany).

Cell preparation and culture. Adipose tissue samples (20 to $80 \mathrm{~g}$ ) were obtained from the mammary adipose of young normal-weight women (body mass index $<26 \mathrm{~kg} / \mathrm{m}^{2}$, age between 18 and 37 years) undergoing surgical mammary reduction. All subjects were otherwise healthy, and had no evidence of diabetes mellitus according to routine laboratory tests. The procedure for obtaining adipose tissue has been approved by the Ethical Committee of the University of Düsseldorf.

Stromal cells from human adipose tissue samples were isolated as described recently [24]. Briefly, the samples were carefully dissected from other tissues, all visible fibrous material and blood vessels were discarded. The remaining adipose tissue was minced into pieces of approximately $10 \mathrm{mg}$ weight and digested in $10 \mathrm{mmol} / 1$ phosphate buffered saline (PBS) containing $1.5 \mathrm{mg} / \mathrm{ml}$ collagenase and $20 \mathrm{mg} / \mathrm{ml}$ bovine serum albumin, $\mathrm{pH}$ 7.4. To obtain full disaggregation the cells were isolated in a two-step procedure. After short centrifugation at $200 \times \mathrm{g}$, the floating fat cells and the incubation solution were removed by aspiration. The sedimented cells were resuspended and incubated with an erythrocyte-lysing buffer consisting of $154 \mathrm{mmol} / \mathrm{l} \mathrm{NH} \mathrm{NH}_{4} \mathrm{Cl} 5.7 \mathrm{mmol} / \mathrm{l} \mathrm{K} \mathrm{K}_{2} \mathrm{HPO}_{4}$, and $0.1 \mathrm{mmol} / \mathrm{l}$ EDTA for $10 \mathrm{~min}$ to remove contaminating erythrocytes. The dispersed material was filtered through a nylon mesh with a pore size of $150 \mu \mathrm{m}$. After additional washing and centrifugation steps, the sedimented cells were resuspended in Dulbecco's Modified Eagle's/Ham's F-12 medium (v/v, $1: 1)$ supplemented with $10 \%$ fetal bovine serum and inoculated into 35 $\mathrm{mm}$ or $100-\mathrm{mm}$ dishes at a density of 30,000 to 50,000 cells per $\mathrm{cm}^{2}$. After a 16-h incubation period, cultures were repeatedly washed with PBS to remove non-adhering material and re-fed with a serum-free medium consisting of Dulbecco's Modified Eagle's/Ham's F-12 medium (v/v, 1:1) supplemented with $15 \mathrm{mmol} / 1 \mathrm{NaHCO}, 15 \mathrm{mmol} / \mathrm{l}$ Hepes, $33 \mu \mathrm{mol} / 1$ biotin, $17 \mu \mathrm{mol} / \mathrm{l}$ pantothenate, $10 \mathrm{mg} / \mathrm{l}$ human transferrin, $100 \mathrm{U} / \mathrm{ml}$ penicillin, and $0.1 \mathrm{~g} / \mathrm{l}$ streptomycin. To induce and maintain adipose differentiation, $100 \mathrm{nmol} / 1$ cortisol, $66 \mathrm{nmol} / 1$ insulin, $0.2 \mathrm{nmol} / \mathrm{l} \mathrm{T}_{3}$ and, for the first 3 days, $0.25 \mathrm{mmol} / \mathrm{l} \mathrm{MIX}$ were added. The medium was changed every $2-3$ days.

Glucose transport assay. 2-Deoxy-D-glucose uptake was determined as a measure of the glucose transport system. Assays were performed in newly differentiated human fat cells cultured in 35-mm dishes. Three days prior to the assay, both insulin and glucose concentrations of the medium were reduced to $20 \mathrm{pmol} / \mathrm{l}$ and $5 \mathrm{mmol} / 1$, respectively, and Hepes was completely removed from the medium. Twenty-four hours before the assay, cells were washed and re-fed with an insulin-free medium. For assessment of the stimulatory effect of insulin on glucose uptake, some dishes were preincubated with $100 \mathrm{nmol} / \mathrm{l}$ insulin for $15 \mathrm{~min}$ immediately before the assay. $\left({ }^{3} \mathrm{H}\right)$-labelled 2 deoxy-D-glucose $(1 \mu \mathrm{Ci} /$ dish, concentration $4.5 \mu \mathrm{mol} / \mathrm{l})$ was added to the medium which already contained $5 \mathrm{mmol} / \mathrm{h}$ glucose and uptake was measured at $37^{\circ} \mathrm{C}$ for $20 \mathrm{~min}$. Glucose transport was terminated by transferring the dishes to an ice-bath. Cells were repeatedly washed using ice-cold PBS and incubated for 20 min with $0.1 \%$ SDS. The radioactivity of the cell material was counted in a liquid scintillation counter (Beckman, Munich, Germany). Values were corrected for the unspecific uptake which was assessed by incubating cells with labelled 2deoxy-D-glucose for $20 \mathrm{~min}$ at $4^{\circ} \mathrm{C}$. A similar unspecific rate of 2-deoxy-D-glucose uptake was obtained, when cells were incubated with $25 \mu \mathrm{mol} / 1$ cytochalasin $B$ for $20 \mathrm{~min}$ (data not shown). 


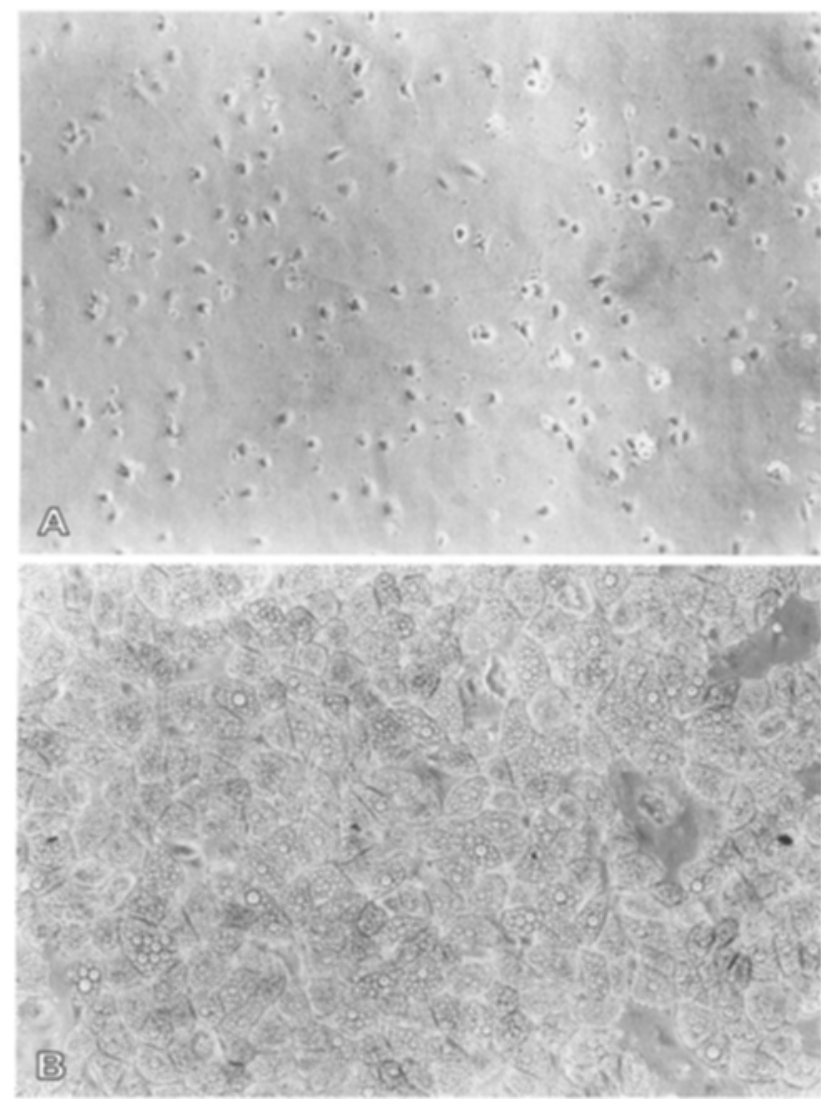

Fig. 1(A, B). Photomicrographs of primary cultures of stromal cells from human adipose tissue $16 \mathrm{~h}$ after inoculation $(\mathbf{A})$ and 16 days after exposure to an adipogenic serum-free medium (B) as described in Methods. Magnification $125 \times$

Preparation of crude membrane fraction. Cells were twice washed in TES buffer $(225 \mathrm{mmol} / \mathrm{l}$ saccharose, $1 \mathrm{mmol} / \mathrm{l}$ EDTA, $20 \mathrm{mmol} / \mathrm{l}$ Tris, $2.5 \mu \mathrm{g} / \mathrm{ml}$ leupeptin, $2.5 \mu \mathrm{g} / \mathrm{ml}$ pepstatin, $2.5 \mu \mathrm{g} / \mathrm{ml}$ aprotinin and $0.2 \mathrm{mmol} / 1$ phenylmethylsulfonyl fluoride, $\mathrm{pH} 7.4$ ). Then cells were scraped from the dishes using a rubber policeman, immediately frozen in liquid nitrogen und stored at $-70^{\circ} \mathrm{C}$. For analysis, the cell material of one sample was homogenized in $10 \mathrm{ml}$ TES buffer using a teflonglass-homogeniser at $4^{\circ} \mathrm{C}$. The first centrifugation was carried out at $1000 \times g$ for $10 \mathrm{~min}$., the supernatant was centrifuged again at $100,000 \times g$ for $90 \mathrm{~min}$. The membrane pellet was resuspended in TES buffer. After a new homogenisation step using a glass-glass-homogenizer the material was stored in aliquots at $-70^{\circ} \mathrm{C}$. The protein content of the samples was determined according to a modification of the Biorad protein assay (Biorad, Munich, Germany).

Western blotting. Prior to Western blotting cells were treated as described for the glucose transport experiments except that $100-\mathrm{mm}$ dishes were used. Membrane protein samples (30 to $50 \mu \mathrm{g}$ ) were subjected to SDS-PAGE and transferred to nitrocellulose filters in a semidry blotting apparatus. Filters were blocked for $10 \mathrm{~min}$ in Tris-buffered saline $(20 \mathrm{mmol} / \mathrm{l}$ Tris/ $\left.\mathrm{HCl}, 137 \mathrm{mmol} / 1 \mathrm{NaCl}, 1 \mathrm{CaCl}_{2}, \mathrm{pH} 7.6\right)$ containing $0.05 \%$ Tween-20 and 5\% BSA. Then, filters were incubated for $16 \mathrm{~h}$ at $4^{\circ} \mathrm{C}$ with a $1: 500$ dilution of a polyclonal GLUT4 antiserum. After extensive washing with Tris-buffered saline containing $0.05 \%$ Tween-20 and $0.5 \% \mathrm{BSA}$, filters were incubated for $2 \mathrm{~h}$ with ${ }^{125} \mathrm{I}$-protein $\mathrm{A}(0.3 \mu \mathrm{Ci} / \mathrm{ml})$ at room tempera- ture. Filters were again extensively washed, airdried and exposed to Hyperfilm-MP films using intensifying screens. Autoradiographs were quantified by laser scanning densitometry (LKB, Gräfelfing, Germany).

Northern blotting. Total RNA was isolated from the cell material using the guanidinium thiocyanate/phenol/chloroform method [25], separated by $2 \%$ agarose gel electrophoresis and transferred to nylon membranes as described previously [26]. Densitometry of ethidium bromide-stained $18 \mathrm{~S} \mathrm{rRNA}$ was used to normalize the amount of RNA loaded per lane. Blots were hybridized either with the oligonucleotide GLUT4 probe which was 5'-labelled to a specific radioactivity of $1.11 \times 10^{8} \mathrm{dpm} / \mu \mathrm{g}$ by using $\left({ }^{32} \mathrm{P}\right)$-ATP and T4-kinase or to a LPL cDNA probe (kindly provided by Dr. A. Singh, Genentech, San Francisco, Calif., USA) multiprime labelled to a specific activity of $2.2 \times 10^{8} \mathrm{dpm} / \mu \mathrm{g}$ by using $\left({ }^{32} \mathrm{P}\right)$-CTP. After washing under high stringency conditions and air-drying, the blots were exposed to MP Hyperfilms at $-70^{\circ} \mathrm{C}$ using intensifying screens. The autoradiographs were quantified by a FUJIX BAS 1000 bioimaging analyser (Fuji, Tokyo, Japan) to determine the relative amounts of GLUT4 and LPL mRNAs.

Lipolysis. The glycerol concentration of the culture medium was used as a measure of lipolysis. The glycerol content was determined by an established bioluminescent method using ATP-linked firefly luciferase [27]. Glycerol concentrations are expressed a $\mu \mathrm{mol}$ glycerol $\cdot \mathrm{mg}$ protein ${ }^{-1} \cdot 24 \mathrm{~h}^{-1}$, but are given as percentage of glycerol concentrations of control cultures.

\section{Statistical analysis}

Results are expressed as mean \pm SEM of at least three experiments in duplicate. Analysis of variance was used for statistical analysis. Comparisons between TNF $\alpha$-treated and untreated cultures were performed using Student's $t$-test for paired data. $p$-values less than 0.05 were considered as statistically significant.

\section{Results}

All experiments on the metabolic effects of TNFa were performed in cultured human adipocyte precursor cells from human adipose tissue after having acquired the adipocyte phenotype under serum-free, hormone-supplemented culture conditions. After 16 days in culture between 50 and $80 \%$ of the cells were differentiated as assessed by microscopic lipid accumulation (Fig. 1) and expression of glycerophosphate dehydrogenase (GPDH) activity. During the following days the functional state of the cells remained stable as assessed by GPDH activity, the morphological appearance of the cells became more spherical with fewer but larger lipid droplets (data not shown).

Effect of TNFa-treatment on 2-deoxy-D-glucose transport. 3 days prior to the glucose transport experiments the newly developed fat cells were changed to a medium devoid of cortisol and $\mathrm{T}_{3}$ but containing 

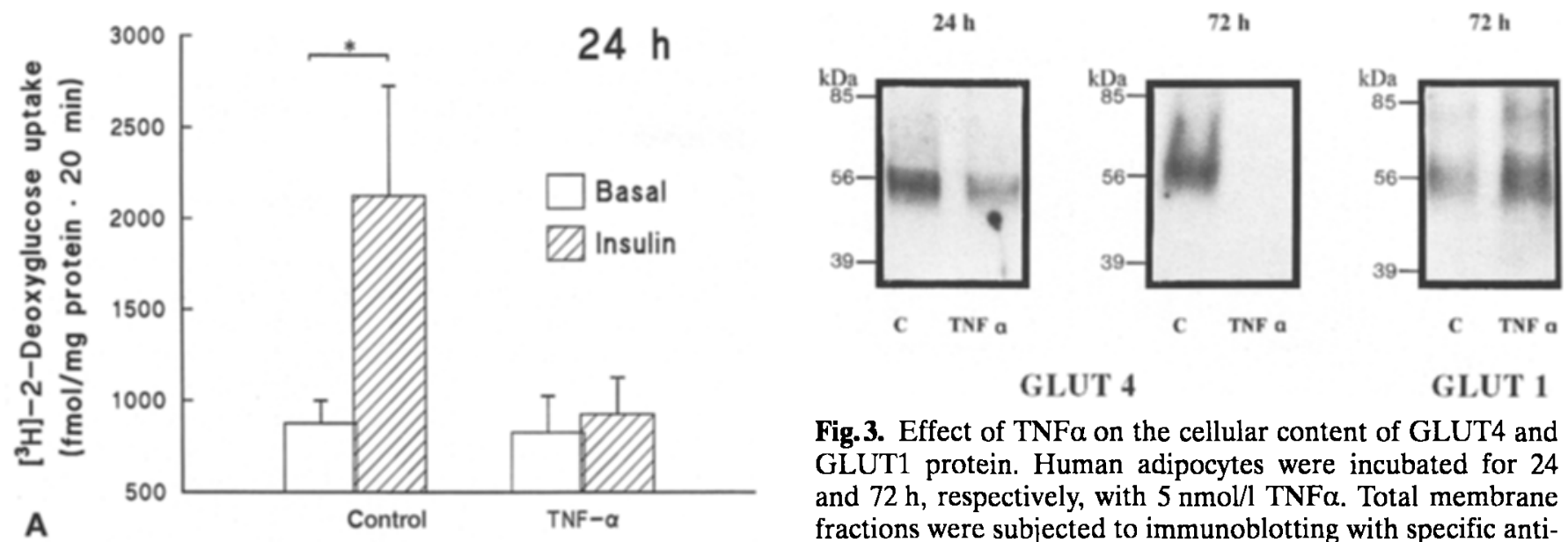

GLUT 4

GLUT 1

Fig.3. Effect of TNF $\alpha$ on the cellular content of GLUT4 and GLUT1 protein. Human adipocytes were incubated for 24 and $72 \mathrm{~h}$, respectively, with $5 \mathrm{nmol} / \mathrm{l} \mathrm{TNF} \alpha$. Total membrane fractions were subjected to immunoblotting with specific antisera, as described in Methods

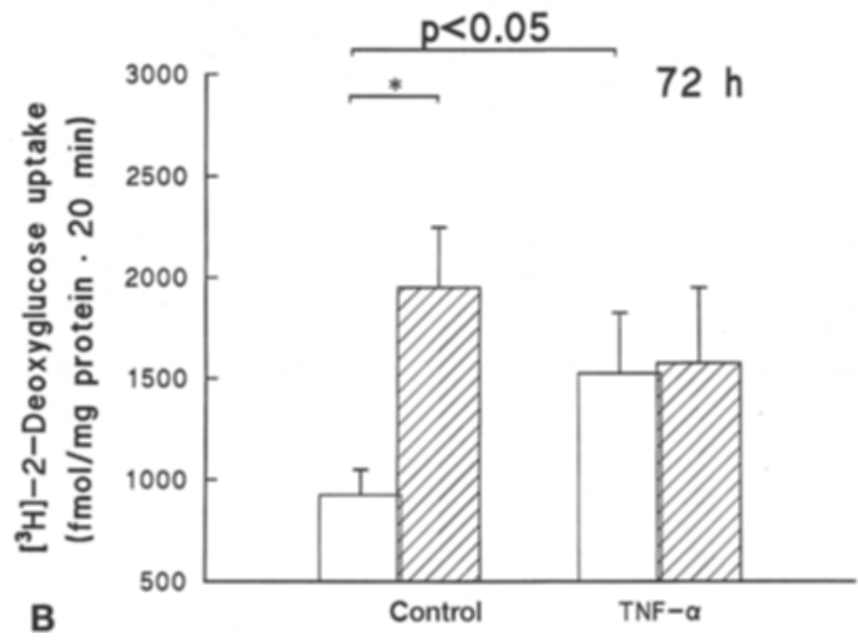

cellular GLUT4 protein content was studied. Total membrane fractions from TNF $\alpha$-treated and untreated cells were prepared and subjected to immunoblotting using a specific antiserum to identify GLUT4. The experiments revealed that TNF $\alpha$ caused a marked reduction in the number of glucose transporters (Fig. 3). Densitometric analysis confirmed a significant decrease in GLUT4 protein. A 24-h exposure of human fat cells to $5 \mathrm{nmol} / 1 \mathrm{TNF} \alpha$ resulted in a reduction of the GLUT4 amount by $49 \pm 3 \%$, a 3 -day exposure to $5 \mathrm{nmol} / 1 \mathrm{TNF} \alpha$ decreased the amount of GLUT4 by approximately $82 \pm 18 \%$. In contrast, TNF $\alpha$ treatment for $24 \mathrm{~h}$ did not significantly alter the amount of GLUT1 protein

Fig.2(A, B). Effect of TNF $\alpha$ on basal and insulin-stimulated 2-deoxy-D-glucose transport in cultured human adipocytes. Cells were prepared for the transport study assay as described under Methods. 2-Deoxy-D-glucose uptake was measured with or without $15-\mathrm{min}$ stimulation of $10^{-7} \mathrm{~mol} / \mathrm{l}$ insulin after a 24-h (A) or 72-h (B) preincubation with $5 \mathrm{nmol} / \mathrm{l} \mathrm{TNF} \alpha$ Data are presented as mean \pm SEM of four experiments in duplicate. ${ }^{*} p<0.01$

$2 \times 10^{-11} \mathrm{~mol} / \mathrm{l}$ insulin. During the final $24 \mathrm{~h}$ cells were cultured in a completely insulin-free medium in the absence or presence of $5 \mathrm{nmol} / \mathrm{l} \mathrm{TNF} \alpha$ A 24-h exposure of the cells to TNF $\alpha$ had no effect on the basal rate of hexose transport but completely abolished the stimulatory action of $10^{-7} \mathrm{~mol} / \mathrm{l}$ insulin on glucose uptake (Fig.2). A 72-h incubation of human fat cells with TNF $\alpha$ resulted in a significantly elevated basal rate of glucose uptake by $71 \pm 13 \% \quad(p<0.01)$. Again, preincubation with insulin failed to increase the rate of 2-deoxy-D-glucose transport (Fig. 2).

Effect of $T N F \alpha$ on the protein expression of the glucose transporters GLUT4 and GLUT1. To determine whether the reduced uptake of 2-deoxy-D-glucose in response to insulin might result from a reduced number of GLUT4 molecules, the effect of TNFa on the (data not shown). A 72-h exposure of fat cells to $\mathrm{TNF} \alpha$ resulted in an almost twofold increase in the total amount of GLUT1 (Fig. 3).

Effect of TNFa on GLUT4 $m R N A$. To examine whether the decrease in the number of GLUT4 transporters in the presence of TNF $\alpha$ was due to a reduced expression of the specific mRNA, Northern blotting was performed to determine the level of GLUT4 mRNA. These experiments demonstrated that exposure of cultured human adipocytes to $5 \mathrm{nmol} / 1 \mathrm{TNF} \alpha$ dramatically decreased the cellular amount of GLUT4 mRNA. As shown in Figure 4A, a 24-h as well as a 72-h incubation with the cytokine was associated with a disappearance of specific mRNA for GLUT4.

Effect of TNF $\alpha$ on LPL $m R N A$. Since the amount of LPL plays a critical role in the uptake of triglycerides by fat cells, the effect of TNF $\alpha$ on the cellular content of LPL mRNA was investigated in additional experiments. After a 24-h incubation with $5 \mathrm{nmol} / \mathrm{l}$ TNF $\alpha$ the amount of LPL mRNA detected by Northern blotting was reduced by approximately $70 \%$. A 72-h exposure of human adipocytes to the same concentration of TNF $\alpha$ resulted in an only moderately 


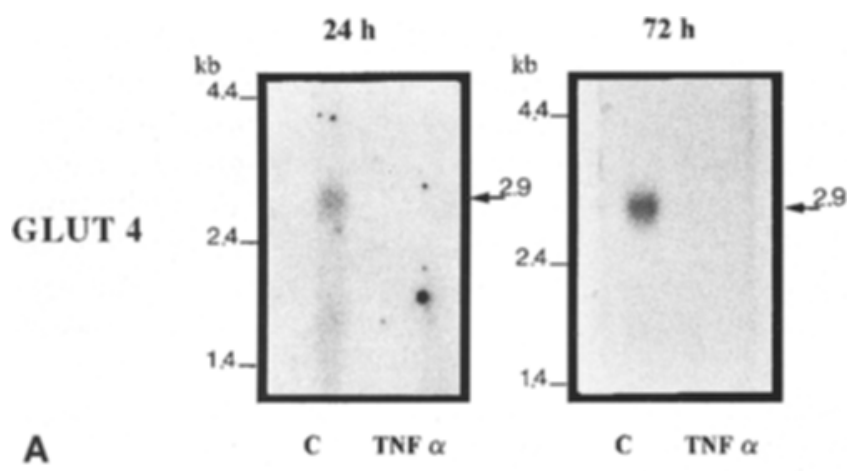

L P L

B

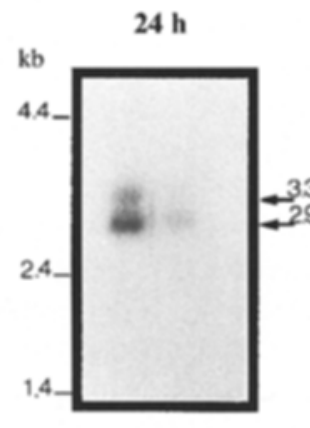

C TNF $\alpha$

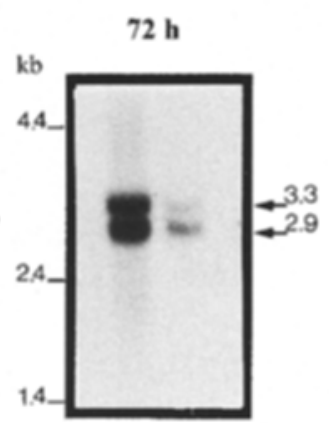

C TNF $\alpha$

Fig. 4A,B. Effect of TNFa on GLUT4 (A) and LPL (B) mRNA content in cultured human fat cells. Adipocytes were exposed to $5 \mathrm{nmol} / \mathrm{l}$ for 24 or $72 \mathrm{~h}$, respectively. Total RNA was electrophoresed, transferred to a nylon membrane and hybridized with specific ${ }^{32} \mathrm{P}$-labelled probes. One representative experiment is shown

higher suppression of LPL mRNA levels by approximately $80 \%$ compared to control cultures (Fig. $4 \mathrm{~B}$ ). These experiments clearly indicate that, similar to its effect on GLUT4, TNF $\alpha$ apparently regulates the amount of LPL at the level of gene expression.

Lipolysis. Another possibility by which TNF $\alpha$ could cause a loss of stored lipids in human adipocytes over time involves a stimulation of the lipolytic system. We therefore investigated the effect of TNF $\alpha$ on the glycerol concentrations in the culture medium. It became apparent that TNF $\alpha$ potently increased lipolysis. When cells were exposed for $24 \mathrm{~h}$ to varying concentrations of the cytokine in the presence of $20 \mathrm{pmol} / 1$ insulin an up to fivefold increase of the glycerol content was observed compared to control cultures (Fig.5). Even at $0.1 \mathrm{nmol} / 1 \mathrm{TNF} \alpha$ the glycerol content of the culture medium was increased by 3.5 -fold. However, the lipolytic activity of TNF $\alpha$ became apparent only after $6 \mathrm{~h}$ suggesting that this effect does not occur via a rapid direct activation of the adenylate cyclase system and subsequent regulatory proteins (Fig.6).

In all experiments with TNFa, treatment of cultures with the cytokine was not associated with de-

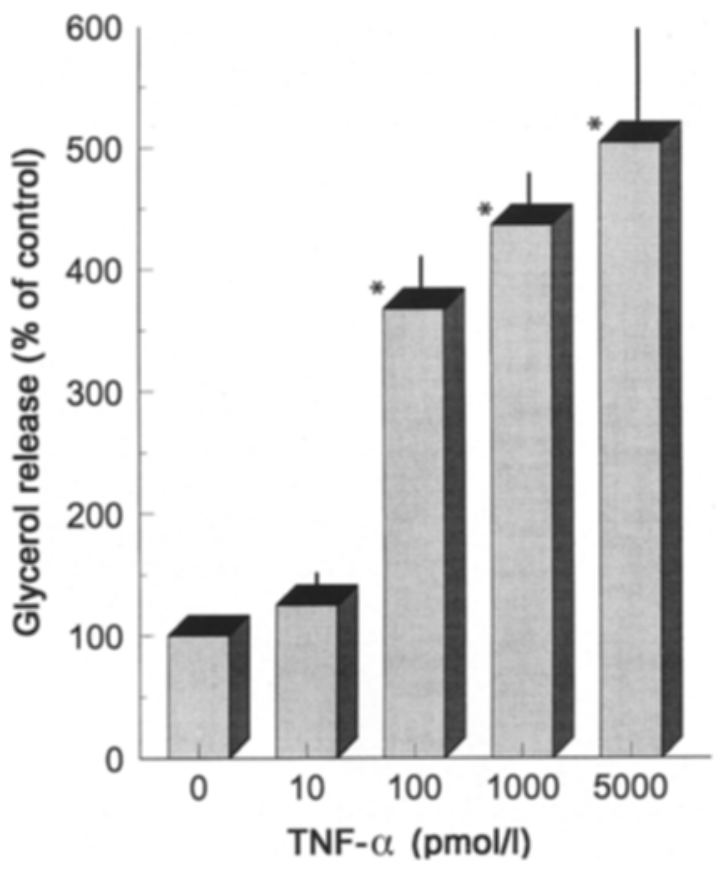

Fig.5. Dose-response-relationship of the effect of TNF $\alpha$ on lipolysis in cultured human adipocytes. Cells were exposed to varying concentrations of TNF $\alpha$ for $24 \mathrm{~h}$ in the absence of insulin. The glycerol content of the culture medium was measured using a bioluminescence method. Results are expressed as percentage of control cultures (mean $\pm \mathrm{SD}: 116 \pm 17 \mu \mathrm{mol} /$ mg protein $/ 24 \mathrm{~h}=100 \%$ ). Data represent mean \pm SEM of five separate experiments in triplicate. ${ }^{*} p<0.05$ vs cultures not exposed to TNFa

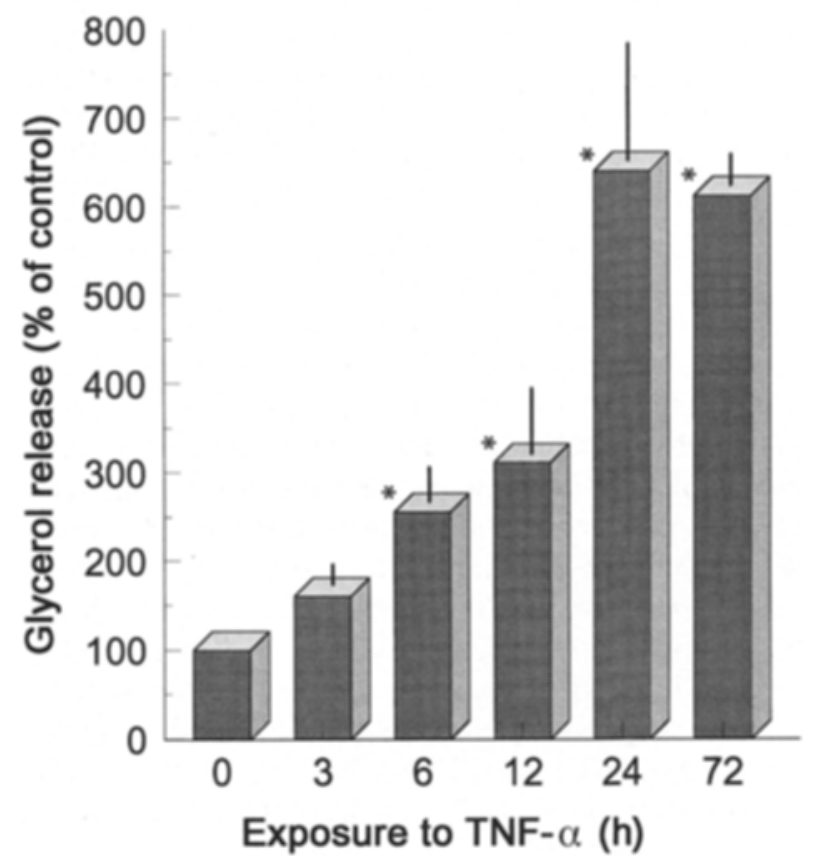

Fig.6. Time-course of the effect of TNF $\alpha$ on lipolysis. Human adipocytes were exposed to $5 \mathrm{nmol} / \mathrm{TNF}$ for the time periods indicated. The glycerol content of the medium was measured as described under Methods. Results are given as percentage of the respective control cultures. Data represent mean \pm SEM of four experiments in triplicate. ${ }^{*} p<0.05$ vs cultures not exposed to TNF $\alpha$ 
tectable changes of cell morphology. In particular, there was no morphological evidence for a cytotoxic effect of TNF $\alpha$ (data not shown).

\section{Discussion}

The results of this study clearly demonstrate that TNF $\alpha$ exerts diverse effects on the main metabolic functions in human adipocytes. TNF $\alpha$ abolished the stimulatory action of insulin on glucose uptake and decreased the cellular GLUT4 protein content. In addition, our experiments indicate that $\mathrm{TNF} \alpha$ also reduces LPL mRNA levels and - in a dose-dependent manner - stimulates the mobilization of stored triglycerides. The combination of these effects may be sufficient to explain the marked delipidation of human adipocytes during long-term exposure to TNF $\alpha$ as reported recently [17].

To study the action of TNF $\alpha$ on human adipose tissue, we used a new cell culture model that is based upon the in vitro differentiation of stromal cells obtained from human adipose tissue samples. In material from young adults up to $80 \%$ of these cells undergo differentiation and develop the biochemical and morphological characteristics of mature fat cells. They express high lipogenic enzyme activing, establish a glucose transport system consisting of GLUT1 and the insulin-responsive GLUT4 subtype and are able to release stored lipids upon stimulation by catecholamines (Hauner et al., unpublished observation). Although most cells exhibit a multilocular morphology, this culture system appears to be a suitable and reliable model to study human fat-cell metabolism for extended periods of time.

One of the best studied effects of TNFa in adipose tissue is suppression of LPL activity [3-8]. The reduced amount of LPL mRNA also found in our study may be due to a specific decrease of LPL gene transcription as originally shown by Zechner et al. [6] in 3T3 L1 adipocytes. However, previous studies on the effect of TNF $\alpha$ on LPL activity and gene expression in human adipose tissue have given conflicting results. In isolated fat cells kept in suspension culture, Kern [15] did not find a change in LPL mRNA induced by $\mathrm{TNF} \alpha$, whereas Fried and Zechner [16] reported a pronounced suppression of LPL synthesis and activity in cultured pieces of human adipose tissue. Our data obtained in fat cells newly developed from precursor cells clearly confirm that TNF $\alpha$ decreases LPL at the mRNA level. It is obvious that the suppression of LPL mRNA by TNF $\alpha$ administration may substantially contribute to the alterations in lipoprotein metabolism, particularly hypertriglyceridaemia, that are frequently seen in patients with chronic infectious diseases or cancer $[1,2]$.

An inhibitory effect of TNF $\alpha$ on GLUT4 expression was originally described in rat L6 myotubes [28] and clonal preadipocytes $[22,23]$. Our experiments clearly extend this observation to human fat cells kept in primary culture. However, the rapid loss of response to insulin seen in the 2-deoxy-D-glucose transport assay cannot be fully explained by the reduction of GLUT4 protein. Recent data indicate that TNF $\alpha$ may also interfere with the transmembrane signalling of insulin. In rat hepatoma cells, a 1-h incubation with TNF $\alpha$ was followed by a dramatic decrease in the insulin-induced tyrosine phosphorylation of both the insulin receptor $\beta$-subunit and IRS-1, its major cytosolic substrate without any reduction in insulin binding [29]. Similar results have been recently reported in 3T3 L1 and 3T3 F442A adipocytes [30]. We therefore assume that the loss of insulin responsiveness observed after a 24-h exposure to TNF $\alpha$ results from both suppression of GLUT4 gene expression and interference with the insulin signal transduction. However, whether the latter mechanism is active in human adipose tissue or whether other factors such as an increase of the lipolytic rate may be of importance for the loss of insulin action, remains to be demonstrated.

Interestingly, after a 3-day exposure to TNFa the basal rate of glucose uptake increased by almost twofold. In conjunction, we also measured a similar increase in the total amount of GLUT1 protein. Experiments in quiescent $3 \mathrm{~T} 3$ fibroblasts indicate that TNF $\alpha$ can enhance glucose uptake by different mechanisms including stabilization of GLUT1 mRNA and alterations in the intrinsic activity of the glucose transporters [31, 32].

Previous studies have revealed that TNF $\alpha$ is also able to stimulate lipolysis in cultured 3T3 L1 adipocytes $[4,9-12]$. We describe here for the first time that TNF $\alpha$ also promotes lipid release from human fat cells. Other evidence for a lipolytic action of TNFa in man was provided from an in vivo study, in which intravenous infusion of TNF $\alpha$ in patients with disseminated cancer resulted in an increase of nonesterified-fatty acid and glycerol levels [33]. The time-course and dose-response relationship for the TNF $\alpha$ effect on lipolysis in human fat cells was similar to those described in 3T3 L1 adipocytes [11]. The delayed stimulation of glycerol release by TNF $\alpha$ indicates that this effect may depend on new protein synthesis. A similar time-course for the effect of TNF $\alpha$ on lipolysis has been recently reported in cultured rat adipocytes with no effect on the expression of hormone-sensitive lipase, the rate-limiting enzyme of lipolysis [12]. A possible role of prostaglandins in mediating the lipolytic action of TNFa has been suggested [11], but this conclusion was withdrawn in a subsequent study [34].

The disturbances of carbohydrate and lipid metabolism observed in this in vitro study of human fat cells may be similar to those present in insulin-resistant states such as NIDDM and obesity. Recent studies in genetically obese rodents have suggested a 
link between an elevated expression of TNF $\alpha$ in adipose tissue and the development of insulin resistance and non-insulin-dependent diabetes. The importance of this association was substantiated by the finding that neutralization of TNF $\alpha$ by a soluble receptor significantly ameliorated insulin sensitivity on glucose utilization [23].

In conclusion, this study demonstrates profound effects of TNF $\alpha$ on metabolic functions of cultured human fat cells. This cytokine suppresses LPL mRNA, potently stimulates lipolysis and was found to abolish the insulin effect on glucose transport. The combination of these effects may be responsible for the delipidation of cultured human fat cells observed under chronic exposure to high concentrations of TNF $\alpha$ and may also contribute to the development of insulin resistance in states of increased $\mathrm{TNF} \alpha$-production.

Acknowledgements. The authors wish to thank Professor R. Olbrisch and his staff from the Department of Plastic Surgery, Düsseldorf-Kaiserswerth, for their cooperation in providing adipose tissue samples. This work was supported by the Ministerium für Wissenschaft und Forschung des Landes Nordrhein-Westfalen, the Bundesministerium für Gesundheit, and the Deutsche Forschungsgemeinschaft (Sonderforschungsbereich 351, Teilprojekt C2, Eckel/Hauner).

\section{References}

1. Grunfeld C, Feingold KR (1991) The metabolic effects of tumor necrosis factor and other cytokines. Biotherapy 3 : 143-158

2. Tracey KJ, Cerami A (1993) Tumor necrosis factor, other cytokines and disease. Annu Rev Cell Biol 9: 317-343

3. Kawakami M, Dekala PH, Lane MD, Cerami A (1982) Lipoprotein lipase suppression in 3T3-L1 cells by an endotoxin induced mediator from exudate cells. Proc Natl Acad Sci USA 79: 912-916

4. Price SR, Olivecrona T, Pekala PH (1986) Regulation of lipoprotein lipase synthesis by recombinant tumor necrosis factor - the primary regulatory role of the hormone in 3T3-L1 adipocytes. Arch Biochem Biophys 251: 738-746

5. Semb H, Peterson J, Tavernier J, Olivecrona T (1987) Multiple effects of tumor necrosis factor on lipoprotein lipase in vivo. J Biol Chem 62: 8390-8394

6. Zechner R, Newman TC, Sherry B, Cerami A, Breslow JL (1988) Recombinant human cachectin/tumor necrosis factor but not interleukin-1 $\alpha$ down-regulates lipoprotein lipase gene expression at the transcriptional level in mouse 3T3-L1 adipocytes. Mol Cell Biol 8: 2394-2401

7. Cornelius P, Enerback S, Bjursell G, Olivecrona T, Pekala PH (1988) Regulation of lipoprotein lipase mRNA content in 3T3-L1 cells by tumour necrosis factor. Biochem J 249: 765-769

8. Grunfeld C, Gulli R, Moser AH, Gavin LA, Feingold KR (1989) The effect of tumor necrosis factor administration in vivo on lipoprotein lipase activity in various tissues of the rat. J Lipid Res 30: 579-585

9. Patton JS, Shepard HM, Wilking $\mathrm{H}$ et al. (1986) Interferons and tumor necrosis factors have similar catabolic effects on 3T3 L1 cells. Proc Natl Acad Sci USA 83: 8313-8317
10. Kawakami M, Murase T, Ogawa H et al. (1987) Human recombinant TNF suppresses lipoprotein lipase activity and stimulates lipolysis in 3T3-L1 cells. J Biochem 101: 331-338

11. Feingold KR, Doerrler W, Dinarello CA, Fiers W, Grunfeld C (1992) Stimulation of lipolysis in cultured fat cells by tumor necrosis factor, interleukin-1, and the interferons is blocked by inhibition of prostaglandin synthesis. Endocrinology 130: 10-16

12. Green A, Dobias SB, Walters DJA, Brasier AR (1994) Tumor necrosis factor increases the rate of lipolysis in primary cultures of adipocytes without altering levels of hormone-sensitive lipase. Endocrinology 134: 2581-2588

13. Feingold KR, Grunfeld C (1987) Tumor necrosis factor alpha stimulates hepatic lipogenesis in the rat in vivo. J Clin Invest 80: 184-190

14. Grunfeld C, Verdier JA, Neese RA, Moser AH, Feingold KR (1988) Mechanisms by which tumor necrosis factor stimulates hepatic fatty acid synthesis in vivo. J Lipid Res 29 : 1327-1335

15. Kern PA (1988) Recombinant human tumor necrosis factor does not inhibit lipoprotein lipase in primary cultures of isolated human adipocytes. J Lipid Res 29: 909-914

16. Fried SK, Zechner R (1989) Cachectin/tumor necrosis factor decreases human adipose tissue lipoprotein lipase mRNA levels, synthesis, and activity. J Lipid Res 30: 19171923

17. Petruschke T, Hauner $H$ (1993) Tumor necrosis factor- $\alpha$ prevents the differentiation of human adipocyte precursor cells and causes delipidation of newly developed fat cells. J Clin Endocrinol Metab 76: 742-747

18. Meszaros K, Lang CH, Bagby GJ, Spitzer JJ (1987) Tumor necrosis factor increases in vivo glucose utilization of macrophage-rich tissues. Biochem Biophys Res Comm 149: 1-6

19. Evans DA, Jacobs DO, Wilmore DW (1989) Tumor necrosis factor enhances glucose uptake by peripheral tissues. Am J Physiol 257: R1182-R1189

20. Sakurai Y, Zhang X, Wolfe RR (1993) Short-term effects of tumor necrosis factor on energy and substrate metabolism in dogs. J Clin Invest 91: 2437-2445

21. Lang CH, Dobrescu C, Bagby GJ (1992) Tumor necrosis factor impairs insulin action on peripheral glucose disposal and hepatic glucose output. Endocrinology 130: 43-52

22. Stephens JM, Pekala PH (1991) Transcriptional repression of the GLUT4 and C/EBP genes in 3T3-L1 adipocytes by tumor necrosis factor- $\alpha$. J Biol Chem 266: 21 839-21845

23. Hotamisligil GS, Shargill NS, Spiegelman BM (1993) Adipose expression of tumor necrosis factor- $\alpha$ : direct role in obesity- linked insulin resistance. Science 259: 87-91

24. Hauner H, Entenmann G, Wabitsch M, Gaillard D, Ailhaud G, Negrel R, Pfeiffer EF (1989) Promoting effects of glucocorticoids on the differentiation of human adipocyte precursor cells cultured in a chemically defined medium. $J$ Clin Invest 34: 1663-1670

25. Chomczynski P, Sacchi N (1987) Single-step method of RNA isolation by acid guanidinium thiocyanate-phenolchloroform extraction. Anal Biochem 162: 156-159

26. Eckel J, Gerlach-Eskuchen E, Reinauer H (1990) G-protein-mediated regulation of the insulin-responsive glucose transporter in isolated cardiac myocytes. Biochem J 272: 691-696

27. Kather H, Wieland E (1984) Glycerol luminometric method. In: Bergmeyer HU (ed) Methods of enzymatic analysis. (3rd edn) Vol. VI Metabolites 1: Carbohydrates. Weinheim Verlag Chemie pp 510-517

28. Cornelius P, Lee MD, Marlowe M, Pekala PH (1989) Monokine regulation of glucose transporter mRNA in L6 myotubes. Biochem Biophys Res Comm 165: 429-436 
29. Feinstein R, Kanety H, Papa MZ, Lunenfeld B, Karasik A (1993) Tumor necrosis factor- $\alpha$ suppresses insulin-induced tyrosine phosphorylation of insulin receptor and its substrates. J Biol Chem 268: 26055-26058

30. Hotamisligil GS, Murray DL, Choy LN, Spiegelman BM (1994) Tumor necrosis factor $\alpha$ inhibits signaling from the insulin receptor. Proc Natl Acad Sci USA 91: 4854-4858

31. Cornelius P, Marlowe M, Lee MD, Pekala PH (1990) Stimulation of glucose transport activity and induction of glucose transporter and immediate early gene expression in 3T3-L1 preadipocytes. J Biol Chem 265: 20506-20516

32. Stephens JM, Carter BZ, Pekala PH, Malter JS (1992) Tumor necrosis factor- $\alpha$-induced glucose transporter (Glut-
1) mRNA stabilization in 3T3-L1 preadipocytes. Regulation by the adenosine-uridine binding factor. J Biol Chem 267: 8336-8341

33. Starnes HF, Warren RS, Jeevanandam M, Gabrilove JL, Larchian W, Oettgen HF, Brennan MF (1988) Tumor necrosis factor and the acute metabolic response to tissue injury in man. J Clin Invest 82: 1321-1325

34. Hardardottir I, Doerrler W, Feingold KR, Grunfeld C (1992) Cytokines stimulate lipolysis and decrease lipoprotein lipase activity in cultured fat cells by a prostaglandin independent mechanism. Biochem Biophys Res Comm 186: 237-243 